\title{
Analisis Indeks Kebutuhan Lahan dan Biaya dari Perencanaan IPAL Terpadu di Kawasan Aerocity $X$
}

\author{
Adryan Lukman Indira ${ }^{1^{*}}$, Didin Agustian Permadi ${ }^{2}$, Etih Hartati ${ }^{3}$ \\ ${ }^{1,2,3}$ Teknik Lingkungan, Fakultas Teknik Sipil dan Perencanaan, Institut Teknologi Nasional (Itenas), Bandung \\ *Koresponden Email: adryan.lukman@ gmail.com
}

Diterima: 18 Mei 2021

Disetujui: 6 Juni 2021

\begin{abstract}
District Aerocity X in Kabupaten Majalengka is a commercial and industrial area that enhances economic growth in Provinsi Jawa Barat. The district with an area of 3,480 ha is integrated into the domestic sector. However, this area also has the potential to cause harm if the waste is not treated. Following PP No 142 Tahun 2015, each industrial area must provide an effective and efficient wastewater treatment plant (WWTP). This design plan begins with the analysis of issues on the study site. The data were obtained using the Aerocity X District Pre-Development Office study method. The method of designing effective alternatives for WWTP used the weighted ranking technique (WRT), each alternative was compared with two fundamental, technical and non-technical aspects. The purpose of this design plan is to analyze the index of land and cost requirements for WWTP. The yield of wastewater was $3.99 \mathrm{~m}^{3} / \mathrm{s}$. The most effective land and the cost is complete mix-activated sludge. The result of installing the design plan requires an area of $9,446.5 \mathrm{~m}^{2} / \mathrm{m}^{3}$ of wastewater and a cost of $\mathrm{Rp} 5,619.53 \times 10^{6} / \mathrm{m}^{3}$ of wastewater.
\end{abstract}

Keywords: district aerocity $x$, complete mix activated sludge, cost requirement, land requirement, wastewater treatment plant

\begin{abstract}
Abstrak
Kawasan Aerocity X di Kabupaten Majalengka merupakan suatu kawasan bisnis dan industri yang mempromosikan pertumbuhan ekonomi Provinsi Jawa Barat. Kawasan dengan lahan seluas 3.480 ha terintegrasi dengan sektor domestik. Kawasan ini berpotensi mencemari lingkungan jika limbahnya tidak diolah. Sesuai PP No 142 Tahun 2015, kawasan industri harus menyediakan instalasi pengolahan air limbah (IPAL) yang efektif dan efisien. Perencanaan ini diawali dengan menganalisis permasalahan di lokasi studi. Data diperoleh menggunakan metode desk study dari laporan pra-pembangunan Kawasan Aerocity X. Metode untuk merancang alternatif IPAL yang efektif menggunakan metode weighted ranking technique (WRT), setiap alternatif dibandingkan dengan dua aspek inti, yaitu aspek teknis dan non teknis. Tujuan perencanaan ini ialah menganalisis indeks kebutuhan lahan dan biaya perencanaan IPAL. Timbulan air limbah didapatkan $3,99 \mathrm{~m}^{3} / \mathrm{s}$. Lahan dan biaya IPAL yang paling efektif adalah complete mix activated sludge, Hasil perencanaan instalasi membutuhkan lahan seluas $9.446,5 \mathrm{~m}^{2} / \mathrm{m}^{3}$ air limbah dan biaya sebesar Rp5.619,53×106/ $\mathrm{m}^{3}$ air limbah.

Kata Kunci: instalasi pengolahan air limbah, kawasan aerocity, complete mix activated sludge, WRT, kebutuhan lahan
\end{abstract}

\section{Pendahuluan}

Kawasan Aerocity $X$ merupakan kawasan bisnis dan industri yang dapat mempromosikan pertumbuhan ekonomi di Provinsi Jawa Barat, khususnya Kabupaten Majalengka. Selain luas lahan kawasan ini yang cukup besar (sekitar 3.480 ha), kawasan ini juga harus memperhatikan limbah sisa produksi yang berpotensi mencemari lingkungan di sekitar kawasan. Limbah yang berpotensi mencemari lingkungan salah satunya berasal dari limbah cair. Mengingat Kawasan Aerocity X adalah kawasan yang terintegrasi maka perlu adanya perencanaan instalasi pengolahan air limbah yang efektif dan efisien sesuai kebutuhan pembangunan mengacu pada PP RI No. 142 Tahun 2015 [1].

Perencanaan instalasi pengolahan air limbah (IPAL) bertujuan untuk menganalisis potensi karakteristik timbulan air limbah, merencanakan unit-unit instalasi yang dibutuhkan sesuai kriteria desain setiap unit, menghitung dimensi unit, hingga menghitung rencana anggaran biaya yang dibutuhkan di Kawasan Aerocity X. Perencanaan ini diawali dengan menganalisis permasalahan di lokasi studi dan mengumpulkan data. Data diperoleh menggunakan metode desk study dari laporan pra-pembangunan Kawasan Aerocity $X$, dimana data yang diambil berupa proyeksi jumlah penduduk, peta wilayah, peta tataguna lahan, dan luas wilayah. Sementara itu, terdapat data yang diambil dari literatur untuk kemudian 
dianalisis dan dikombinasikan, data yang diambil meliputi standar kebutuhan air bersih dan air limbah, baku mutu kawasan industri yang serupa, serta kriteria desain unit pengolahan IPAL. Perencanaan IPAL dibagi menjadi dua tahap, yaitu analisis kualitas air limbah dan estimasi kuantitas air limbah. Perhitungan kebutuhan air bersih di Kawasan Aerocity $X$ dilakukan dengan menghitung kebutuhan air yang diperlukan untuk kebutuhan domestik dan non domestik, selanjutnya dengan mempertimbangkan faktor air limbah yang ditimbulkan dari hasil aktivitas maka didapatkan kuantitas timbulan air limbah Kawasan. Metode yang digunakan untuk mengetahui rancangan alternatif IPAL yang efektif menggunakan metode weighted ranking technique (WRT), setiap alternatif akan dibandingkan dengan dua parameter (aspek) inti, yaitu aspek teknis dan non teknis. Aspek teknis terdiri atas kemudahan pengoperasian, ketersediaan sumber daya manusia, jumlah lumpur yang dihasilkan, dan kualitas efluen. Sedangkan aspek non teknis meliputi ketersediaan lahan, dan biaya investasi [2] [3].

Kawasan Aerocity $X$ perlu pengawasan yang ketat terkait air limbah sisa-sisa produksi dari beberapa industri dalam kawasannya. Perencanaan instalasi pengolahan air limbah dapat mengurangi kandungan air limbah industri agar tetap memenuhi baku mutu air limbah ketika dibuang ke lingkungan. Perencanaan ini diharapkan memberikan gambaran mengenai teknologi pengolahan air limbah yang efektif dan efisien untuk mengolah air limbah serta dapat diterapkan di Kawasan Aerocity X Kabupaten Majalengka.

\section{Metode Penelitian \\ Lokasi Penelitian}

Pada perencanaan ini, lokasi perencanaan dilakukan di Kabupaten Majalengka. Sasaran objek perencanaan adalah Kawasan Industri Aerocity X. Perencanaan instalasi pengolahan air limbah dilakukan dengan mengestimasi debit air bersih. Perhitungan kebutuhan air bersih atau debit air bersih membutuhkan data pendukung seperti standar kebutuhan air yang bisa didapatkan dari data sekunder. Berikut ini adalah rumus perhitungan debit air bersih.

$$
\mathrm{Q}_{\text {air bersih }}(\mathrm{L} / \mathrm{hari})=\text { Populasi (jiwa) } \times \text { Standar kebutuhan air }(\mathrm{L} / \mathrm{jiwa} / \mathrm{hari})
$$

Kemudian debit air limbah dihasilkan dari sisa-sisa kegiatan domestik dan non domestik. Perhitungan debit air limbah menggunakan faktor maksimum harian, dalam perencanaan ini timbulan air limbah memperhitungkan timbulan terbanyak dalam satu hari selama satu tahun. Perhitungan debit timbulan air limbah dapat dilihat sebagai berikut.

$$
\begin{aligned}
& \mathrm{Q}_{\text {air limbah }}(\mathrm{L} / \text { hari })=\text { Faktor air limbah }(\%) \times \mathrm{Q}_{\text {air bersih }}(\mathrm{L} / \mathrm{hari}) \times \mathrm{F}_{\mathrm{P}}[4] \\
& \text { Dimana } \mathrm{F}_{\mathrm{P}}=\text { faktor maksimum harian. }
\end{aligned}
$$

Penentuan Penentuan alternatif IPAL yang akan diterapkan pada Kawasan Aerocity X menggunakan metode Weighted Ranking Technique (WRT) dengan mempertimbangkan aspek teknis dan non teknis. Metode WRT membandingkan setiap parameter dengan memberikan nilai yang bersifat kuantitatif. Metode WRT juga merupakan metode yang sangat umum digunakan dalam suatu perencanaan. Metode WRT memberikan penilaian terhadap beberapa alternatif yang nantinya dibandingkan dengan nilai paling tinggi. Penentuan nilai dalam metode WRT menggunakan koefisien penting faktor (KPF) dan koefisien pemilihan alternatif (KPA). Koefisien penting faktor atau KPF ditentukan dengan cara memberikan bobot pada masing-masing faktor pembanding berdasarkan tingkat kepentingan faktor terhadap persyaratan yang ada. Koefisien pemilihan alternatif (KPA) didapatkan dengan cara memberikan bobot untuk membandingkan alternatif satu dengan alternatif lainnya dalam satu faktor pembanding. Pengambilan keputusan merupakan tahap terakhir dalam metode WRT, dimana nilai tertinggi dari hasil perkalian KPF dan KPA dari setiap alternatif akan dipilih[5][6].

\section{Pengolahan Data}

Jenis data yang digunakan dalam perencanaan ini adalah data sekunder, pengambilan data sekunder dilakukan dengan metode desk study. Data perhitungan yang telah didapatkan digunakan untuk perencanaan dimensi instalasi air limbah dan menghitung rencana anggaran biaya yang dibutuhkan. Informasi lainnya berupa data kualitatif akan digunakan untuk menganalisis kualitas air limbah di Kawasan Aerocity X. 


\section{Hasil dan Pembahasan \\ Karakteristik Air Limbah}

Karakteristik air limbah di Kawasan Aerocity $X$ Kabupaten Majalengka direncanakan dengan pendekatan baku mutu kawasan industri yang ada di Indonesia, yaitu PT Jababeka Tbk., PT Kawasan Berikat Nusantara (Persero), PT Surabaya Industrial Estate Rungkut, dan baku mutu dari bandara internasional yang sudah mengusung konsep aerocity, yaitu Bandara Internasional Incheon, Bandara Internasional Indira Gandhi, dan Bandara Internasional Kansai. Pendekatan ini dilakukan dengan membandingkan efisiensi penyisihan setiap parameter, dan dipilih yang paling besar yang dapat mengolah air limbah mendekati baku mutu outlet PermenLH No. 03 tahun 2010. Rencana baku mutu kawasan Aerocity $X$ di Kabupaten Majalengka dapat dilihat pada Tabel 1[7].

$\underline{\text { Tabel 1. Perencanaan baku mutu kawasan Aerocity } X \text { di Kabupaten Majalengka }}$

\begin{tabular}{|c|c|c|c|}
\hline Parameter & Unit & $\mathrm{I}$ & II \\
\hline Temperatur & ${ }^{\circ} \mathrm{C}$ & 38 & 40 \\
\hline TDS & $\mathrm{mg} / \mathrm{l}$ & 2 & 2,000 \\
\hline TSS & $\mathrm{mg} / \mathrm{l}$ & 30 & 400 \\
\hline Amonia Total (NH3-N) & $\mathrm{mg} / \mathrm{l}$ & - & 10 \\
\hline Besi (Fe) & $\mathrm{mg} / \mathrm{l}$ & - & 5 \\
\hline Mangan (Mn) & $\mathrm{mg} / \mathrm{l}$ & - & 2 \\
\hline Total Merkuri (Hg) & $\mathrm{mg} / \mathrm{l}$ & 0,005 & 0,002 \\
\hline Barium (Ba) & $\mathrm{mg} / \mathrm{l}$ & - & 2 \\
\hline Tembaga $(\mathrm{Cu})$ & $\mathrm{mg} / \mathrm{l}$ & 0,2 & 2 \\
\hline Seng $(Z n)$ & $\mathrm{mg} / \mathrm{l}$ & 2 & 5 \\
\hline Krom Heksavalen $(\mathrm{Cr}+6)$ & $\mathrm{mg} / \mathrm{l}$ & 1 & 0,1 \\
\hline Krom Total $(\mathrm{Cr})$ & $\mathrm{mg} / \mathrm{l}$ & - & 0,5 \\
\hline Cadmium (Cd) & $\mathrm{mg} / \mathrm{l}$ & 0,01 & 0,05 \\
\hline Timbah $(\mathrm{Pb})$ & $\mathrm{mg} / \mathrm{l}$ & 1 & 0.1 \\
\hline Stannum (Sn) & $\mathrm{mg} / \mathrm{l}$ & - & 2 \\
\hline Arsen (As) & $\mathrm{mg} / \mathrm{l}$ & - & 0,1 \\
\hline Selenium (Se) & $\mathrm{mg} / \mathrm{l}$ & 0,05 & 0,05 \\
\hline Nikel (Ni) & $\mathrm{mg} / \mathrm{l}$ & - & 0,2 \\
\hline Kobalt (Co) & $\mathrm{mg} / \mathrm{l}$ & 0,2 & 0,4 \\
\hline Sianida $(\mathrm{CN})$ & $\mathrm{mg} / \mathrm{l}$ & - & 0,05 \\
\hline Parameter & Unit & I & II \\
\hline Sulfida (S dan H2S) & $\mathrm{mg} / \mathrm{l}$ & - & 0,1 \\
\hline Fluor $(\mathrm{F})$ & $\mathrm{mg} / \mathrm{l}$ & - & 2 \\
\hline Gas Klorin & $\mathrm{mg} / \mathrm{l}$ & - & 1 \\
\hline Amonia Bebas (NH3-N) & $\mathrm{mg} / \mathrm{l}$ & - & 1 \\
\hline Nitrat (NO3-N) & $\mathrm{mg} / \mathrm{l}$ & 20 & 30 \\
\hline Nitrit (NO2-N) & $\mathrm{mg} / \mathrm{l}$ & - & 2 \\
\hline BOD & $\mathrm{mg} / \mathrm{l}$ & 50 & 540 \\
\hline COD & $\mathrm{mg} / \mathrm{l}$ & 100 & 850 \\
\hline Methylene Blue Active Surfactant & $\mathrm{mg} / \mathrm{l}$ & - & 5 \\
\hline Fenol & $\mathrm{mg} / \mathrm{l}$ & - & 0,5 \\
\hline
\end{tabular}

Sumber: Hasil perhitungan peneliti, 2019

\section{Estimasi Timbulan Air Limbah}

Estimasi kebutuhan air bersih pada kawasan Aerocity $X$ dapat dihitung menggunakan data jumlah penduduk/pegawai dikali standar kebutuhan air bersih setiap fasilitas yang tersedia. Selanjutnya estimasi timbulan limbah domestik dihitung dengan cara mengalikan kebutuhan air bersih dengan faktor air limbah. Perhitungan kebutuhan air bersih dan timbulan air limbah dapat dilihat sebagai berikut.

Perhitungan kebutuhan air domestik pada tahun 2045, diketahui:

- Jumlah populasi (pegawai) pada sektor aircraft manufacturing=2.208 jiwa.

- Standar kebutuhan air sektor aircraft manufacturing=50 L/pegawai/hari.

Maka, Kebutuhan Air Domestik $($ Qabdom $)=$ Populasi $($ jiwa $) \times$ Standar kebutuhan air $(\mathrm{L} / \mathrm{jiwa} / \mathrm{hari})$

Qabdom=2.208 jiwa $\times 50 \mathrm{~L} /$ pegawai/hari

Qabdom $=110.400 \mathrm{~L} / \mathrm{hari}$

Perhitungan timbulan air limbah domestik pada tahun 2045, diketahui:

- Kebutuhan air bersih domestik pada fasilitas aircraft manufacturing $=110.400 \mathrm{~L} / \mathrm{hari}$

- Faktor air limbah fasilitas aircraft manufacturing $=80 \%$. 
- Faktor maksimum harian=1,61

Maka, Debit Air Limbah $(\mathrm{Qal})=$ Faktor air limbah $(\%) \times$ Qabdom $(\mathrm{L} / \mathrm{hari}) \times \mathrm{Fp}$

$\mathrm{Qal}=80 \% \times 110.400 \mathrm{~L} / \mathrm{hari} \times 1,61$

Qal $=142.195 \mathrm{~L} / \mathrm{hari}$

Perhitungan timbulan air limbah pada tahun akhir perencanaan dapat dilihat pada Tabel 2.

Tabel 2. Rekapitulasi perhitungan timbulan air limbah tahun 2045

\begin{tabular}{|c|c|c|}
\hline Fasilitas & Satuan & $\begin{array}{l}\text { Tahun } \\
2045\end{array}$ \\
\hline \multicolumn{3}{|l|}{ Aerospace Park Cluster } \\
\hline Aircraft Manufacturing & L/hari & 142.195 \\
\hline $\begin{array}{r}\text { Staff in Maintenance, Repairing, \& Overhaul } \\
\text { Logistic Hub Cluster }\end{array}$ & L/hari & 133.879 \\
\hline Staff in Logistic (Warehouse \& Cargo Handling) & L/hari & 3.224 \\
\hline Staff in Logistic (Land Distribution) & L/hari & 5,41 \\
\hline Staff in E-Commerce & L/hari & 57.154 \\
\hline \multicolumn{3}{|l|}{ Creative Technology Center } \\
\hline Staff in Bio-life Science (Pharmacy) & L/hari & 51.728 \\
\hline Staff in Smartphone Manufacturing & L/hari & 446.614 \\
\hline Staff in Garment & $\mathrm{L} / \mathrm{hari}$ & 5.663 .658 \\
\hline Student in University & L/hari & 1.056 .000 \\
\hline Staff in ISP \& Data Center Provider & L/hari & 12.452 \\
\hline Total Bed in Hospital & L/hari & 506,88 \\
\hline Staff in Hospital & $\mathrm{L} / \mathrm{hari}$ & 77.146 \\
\hline \multicolumn{3}{|l|}{ Business Park Cluster } \\
\hline Staff in Financial Center & L/hari & 22.566 \\
\hline Total Retail Building Floor Area & L/hari & 31.893 \\
\hline Staff in Retail & L/hari & 37.75 \\
\hline Guest in Hotel & L/hari & 170.311 .352 \\
\hline Staff in Hotel & L/hari & 47,33 \\
\hline Resident in Apartment & L/hari & 34.286 .340 \\
\hline \multicolumn{3}{|l|}{ Residential } \\
\hline Individual Housing & L/hari & 1.870 .560 \\
\hline Individual and High Class Housing & $\mathrm{L} / \mathrm{hari}$ & 15.588 .400 \\
\hline \multicolumn{3}{|l|}{ Energy Cluster } \\
\hline Staff in Utility - Electricity & L/hari & 40.807 \\
\hline Staff in Utility - Water & L/hari & 2.176 \\
\hline Staff in Utility - Waste Management & L/hari & 2.176 \\
\hline \multicolumn{3}{|l|}{ Accessibility } \\
\hline Other (Community Facilities \& Green Area) 1 & L/hari & 20.088 \\
\hline Other (Community Facilities \& Green Area) 1 & L/hari & 96.805 .176 \\
\hline 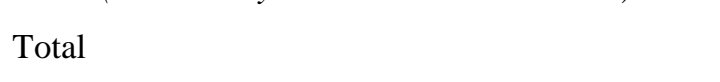 & $\begin{array}{c}\mathrm{L} / \mathrm{hari} \\
\mathrm{m}^{3} / \mathrm{s}\end{array}$ & $\begin{array}{c}327.222 .951 \\
3,787\end{array}$ \\
\hline
\end{tabular}

Sumber: Hasil perhitungan peneliti, 2019

Estimasi timbulan air limbah yang dihitung hanya timbulan air limbah domestik, di samping itu timbulan air limbah non domestik didapatkan dari data sekunder proyeksi timbulan air limbah industri. Rekapitulasi timbulan air limbah maksimum pada tahun akhir perencanaan dapat dilihat pada Tabel 3.

Tabel 3. Rekapitulasi timbulan air limbah maksimum tahun 2045

\begin{tabular}{ccc}
\hline Keterangan & Satuan & $\begin{array}{c}\text { Tahun } \\
2045\end{array}$ \\
\hline Timbulan Air Limbah Domestik & $\mathrm{m}^{3} / \mathrm{s}$ & 3,787 \\
Timbulan Air Limbah Industri & $\mathrm{m}^{3} / \mathrm{s}$ & 0,207 \\
Total Timbulan Air Limbah & $\mathrm{m}^{3} / \mathrm{s}$ & 3,99 \\
\hline \multicolumn{2}{c}{ Sumber: Hasil perhitungan peneliti, 2019}
\end{tabular}

\section{Pemilihan Alternatif Instalasi Pengolahan Air Limbah}

Berdasarkan data baku mutu air limbah dan timbulan air limbah, dapat diketahui tipe dekomposisi dari air limbah di kawasan Aerocity $X$ yang nantinya mempengaruhi efektivitas teknologi IPAL yang dibutuhkan. Tipe dekomposisi aerobik cocok untuk mengolah kuantitas air limbah yang besar dengan 
kualitas BOD $<500 \mathrm{mg} / \mathrm{l}$. Maka, tipe dekomposisi air limbah di Kawasan Aerocity $X$ tergolong dalam tipe dekomposisi aerobik, sehingga alternatif pengolahan IPAL lebih banyak menggunakan sistem aerobik. Alternatif pengolahan seperti Facultative Ponds (FP), Complete Mix Activated Sludge (CMAS), Oxidation Ditch (OD), Sequencing Batch Reactor (SBR), Trickling Filter (TF), dan Rotating Biological Contactors $(R B C)$ akan dibandingkan dengan enam parameter pembanding (terdiri atas parameter teknis dan parameter non teknis) untuk mengetahui teknologi yang dapat diterapkan di Kawasan Aerocity X. Perbandingan alternatif pengolahan dapat dilihat pada Tabel 4 dan Tabel 5 [8], [9][6], [10][11].

Tabel 4. Perbandingan alternatif teknologi pengolahan berdasarkan aspek teknis

\begin{tabular}{|c|c|c|c|c|}
\hline Teknologi & 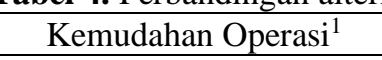 & $\mathrm{SDM}^{1}$ & Jumlah Lumpur $^{2}$ & Kualitas Efluen $^{2}$ \\
\hline FP & $\begin{array}{c}\text { Manhole, Fencing, } \\
\text { Transfer pipe }\end{array}$ & $\begin{array}{l}\text { Tidak perlu } \\
\text { SDM }\end{array}$ & $\begin{array}{l}30-60 \% \text { BOD } \\
\text { removal }\end{array}$ & $80-95 \%$ \\
\hline CMAS & $\begin{array}{c}\text { Diffused air, Mechanical } \\
\text { aerators }\end{array}$ & $\begin{array}{l}\text { Harus } \\
\text { berkompeten }\end{array}$ & $\begin{array}{l}30-60 \% \text { BOD } \\
\text { removal }\end{array}$ & $85 \%-95 \%$ \\
\hline OD & $\begin{array}{c}\text { Diffused air, Mechanical } \\
\text { aerators }\end{array}$ & $\begin{array}{c}\text { Harus } \\
\text { berkompeten }\end{array}$ & $\begin{array}{l}30-60 \% \text { BOD } \\
\text { removal }\end{array}$ & $75-95 \%$ \\
\hline SBR & $\begin{array}{l}\text { Diffused air, Mechanical } \\
\text { aerators, Decanters }\end{array}$ & $\begin{array}{l}\text { Harus } \\
\text { berkompeten }\end{array}$ & $\begin{array}{l}30-60 \% \text { BOD } \\
\text { removal }\end{array}$ & $85-95 \%$ \\
\hline $\mathrm{TF}$ & Media filter, Ventilator & $\begin{array}{c}\text { Tanpa keahlian } \\
\text { khusus }\end{array}$ & $\begin{array}{l}10-30 \% \text { BOD } \\
\text { removal }\end{array}$ & $40-85 \%$ \\
\hline $\mathrm{RBC}$ & Media filter (Disks), Shaft & $\begin{array}{c}\text { Tanpa keahlian } \\
\text { khusus }\end{array}$ & $\begin{array}{l}\text { 10-30\% BOD } \\
\text { removal }\end{array}$ & $80-90 \%$ \\
\hline
\end{tabular}

Sumber: [8], [9]

Tabel 5. Perbandingan alternatif teknologi pengolahan berdasarkan aspek non teknis

\begin{tabular}{lcc}
\hline Teknologi & Kebutuhan Lahan & Biaya Konstruksi $(\mathrm{Rp})$ \\
\hline$F P$ & $10,93 \mathrm{~m}^{2} / \mathrm{m}^{3}$ air limbah & $55.514 \times 10^{3} /$ P.E \\
$C M A S$ & $0,04 \mathrm{~m}^{2} / \mathrm{m}^{3}$ air limbah & $74.191 \times 10^{3} /$ P.E \\
$O D$ & $0,33 \mathrm{~m}^{2} / \mathrm{m}^{3}$ air limbah & $1.575 .442 \times 10^{3} / \mathrm{P} . \mathrm{E}$ \\
$S B R$ & $0,26 \mathrm{~m}^{2} / \mathrm{m}^{3}$ air limbah & $23.511 .579 \times 10^{3} /$ P.E \\
$T F$ & $1 \mathrm{~m}^{2} / \mathrm{m}^{3}$ air limbah & $49.395 .009 \times 10^{3} /$ P.E \\
$R B C$ & $0,08 \mathrm{~m}^{2} / \mathrm{m}^{3}$ air limbah & $10.993 .191 \times 10^{3} / \mathrm{P} . \mathrm{E}$ \\
\hline
\end{tabular}

Sumber: Hasil perhitungan peneliti, 2019

Metode yang digunakan dalam perencanaan ini untuk mengonversikan pertimbangan alternatif menjadi sebuah nilai adalah metode WRT (Weighted Ranking Technique). Pembobotan metode WRT adalah membandingkan faktor pembanding satu dengan lainnya, sehingga didapatkan koefisien pentingnya faktor (KPF) dan menentukan nilai koefisien pentingnya angka (KPA). Pemilihan alternatif terbaik ditentukan dengan mengalikan nilai KPF dan KPA, dan dicari hasil yang paling tinggi. Rekapitulasi perhitungan KPF dan KPA dapat dilihat pada Tabel 6. Hasil perbandingan menggunakan metode WRT teknologi yang memiliki bobot tertinggi adalah Complete Mix Activated Sludge (CMAS)[6], [12].

Tabel 6. Rekapitulasi hasil perhitungan KPF dan KPA

\begin{tabular}{ccccccc}
\hline Parameter & FP & CMAS & OD & SBR & TF & RBC \\
\hline Kemudahan Operasi & 0,04 & 0,028 & 0,028 & 0,016 & 0,004 & 0,004 \\
SDM & 0,04 & 0,008 & 0,008 & 0,008 & 0,028 & 0,028 \\
Jumlah Lumpur & 0,04 & 0,016 & 0,00 & 0,008 & 0,028 & 0,028 \\
Kualitas Efluen & 0,00 & 0,036 & 0,016 & 0,036 & 0,008 & 0,024 \\
Kebutuhan Lahan & 0,00 & 0,04 & 0,024 & 0,008 & 0,016 & 0,032 \\
Capital Cost & 0,036 & 0,032 & 0,00 & 0,016 & 0,008 & 0,028 \\
Jumlah & 0,155 & 0,159 & 0,075 & 0,091 & 0,091 & 0,143 \\
\hline
\end{tabular}

Sumber: Hasil perhitungan peneliti, 2019

Berdasarkan Tabel 6, teknologi terpilih adalah Complete Mix Activated Sludge (CMAS) dengan rangkaian sistem pengolahan dapat dilihat pada Gambar 1. 


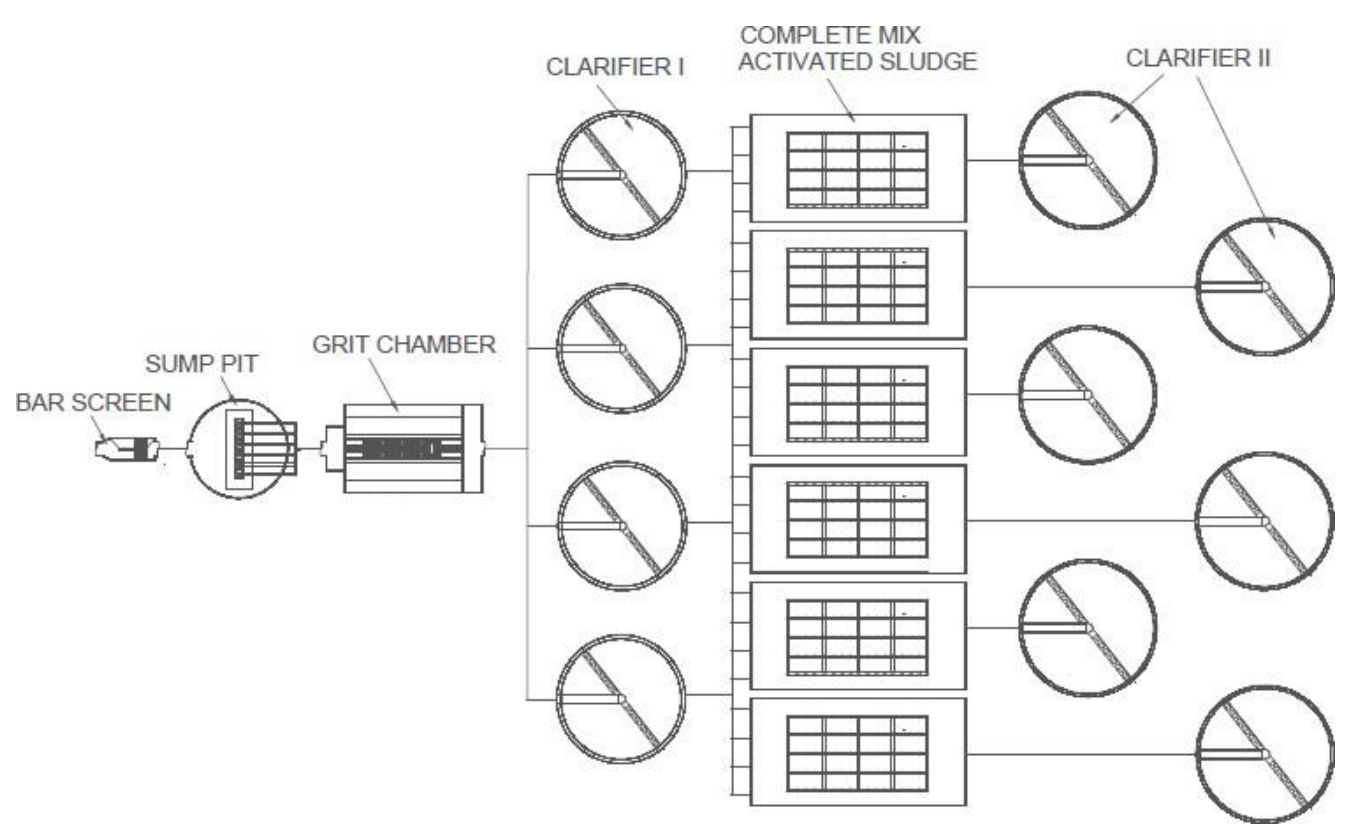

Gambar 1. Rangkaian sistem pengolahan air limbah menggunakan teknologi CMAS Sumber: Hasil analisis peneliti, 2020

\section{Perencanaan Instalasi Pengolahan Air Limbah}

Perencanaan IPAL Kawasan Aerocity $X$ diawali dengan menghitung dimensi unit saluran pembawa dan bar screen dimana pada perencanaannya disediakan dua jenis bar screen untuk mengantisipasi ketika terjadi kerusakan. Hasil perencanaan unit bar screen dapat dilihat pada Tabel 7. Perhitungan dimensi unit saluran pembawa dan bar screen sebagai berikut.

Menghitung luas saluran pembawa air limbah, dengan kecepatan memasuki saluran pembawa direncanakan $0,5 \mathrm{~m} / \mathrm{s}$.

- $\mathrm{A}=\mathrm{Qr} / \mathrm{v}$ approach

$\mathrm{A}=1,9 \mathrm{~m}^{3} / \mathrm{s} / 0,5 \mathrm{~m} / \mathrm{s}$

$\mathrm{A}=3,8 \mathrm{~m}^{2}$

Menghitung dimensi saluran pembawa. Jika rasio kedalaman: lebar adalah 1,5:1.

- $\mathrm{A}=\mathrm{h} \times \mathrm{L}$

$\mathrm{A}=(1,5 \mathrm{~L}) \times \mathrm{L}$

$\mathrm{L}=(\mathrm{A} / 1,5)^{0,5}$

$\mathrm{L}=\left(3,8 \mathrm{~m}^{2} / 1,5\right)^{0,5}$

$\mathrm{L}=1,6 \mathrm{~m}$

Menghitung luas saluran pembawa air limbah, dengan debit maksimum.

- $\mathrm{A}=\mathrm{Qr} / \mathrm{v}$ approach

$\mathrm{A}=3,99 \mathrm{~m}^{3} / \mathrm{s} / 0,5 \mathrm{~m} / \mathrm{s}$

$\mathrm{A}=7,98 \mathrm{~m}^{2}$

Menghitung dimensi saluran pembawa pada kondisi maksimum dengan lebar saluran 1,6 m.

- $\mathrm{A}=\mathrm{h} \times \mathrm{L}$

$\mathrm{h}=\mathrm{A} / \mathrm{L}$

$\mathrm{h}=7,98 \mathrm{~m}^{2} / 1,6 \mathrm{~m}$

$\mathrm{h}=5 \mathrm{~m}$

Menghitung jumlah bar yang digunakan. Perencanaan lebar bar sebesar $15 \mathrm{~mm}(0,015 \mathrm{~m})$ dan bukaan bar sebesar $30 \mathrm{~mm}(0,03 \mathrm{~m})$.

- Jumlah bar= (lebar saluran - bukaan bar) / (lebar bar + bukaan bar $)$

Jumlah bar $=(1,6 \mathrm{~m}-0,03 \mathrm{~m}) /(0,015+0,03 \mathrm{~m})$

Jumlah bar $=34$ buah 
Tabel 7. Rekapitulasi hasil perencanaan dimensi unit Bar Screen

\begin{tabular}{lcc}
\multicolumn{1}{c}{ Uraian } & Satuan & Nilai \\
\hline Saluran Pembawa & & \\
Bahan dasar saluran pembawa & beton \\
Jumlah Saluran Pembawa & unit & 2 \\
Kecepatan (vapproach) & & \\
Kondisi debit maksimum & $\mathrm{m} / \mathrm{s}$ & 0,65 \\
Kondisi debit rata-rata & $\mathrm{m} / \mathrm{s}$ & 0,59 \\
Kondisi debit minimum & $\mathrm{m} / \mathrm{s}$ & 0,53 \\
Kedalaman & $\mathrm{m}$ & 5 \\
Lebar & $\mathrm{m}$ & 1,6 \\
Mechanical Bar Screen & & \\
Lebar bar & $\mathrm{mm}$ & 15 \\
Jarak antar bar atau bukaan & $\mathrm{mm}$ & 30 \\
Kemiringan bar (dari vertikal) & derajat & 30 \\
Jumlah bar & buah & 34 \\
Headloss & & \\
Kondisi tidak tersumbat & $\mathrm{mm}$ & 13,15 \\
Kondisi tersumbat & $\mathrm{mm}$ & 146,83 \\
Manual Bar Screen & & \\
Lebar bar & $\mathrm{mm}$ & 15 \\
Jarak antar bar atau bukaan & $\mathrm{mm}$ & 25 \\
Kemiringan bar (dari vertikal) & derajat & 30 \\
Jumlah bar & buah & 39 \\
Headloss & $\mathrm{mm}$ & 18,18 \\
\hline \multicolumn{2}{c}{ Sumber: Hasil perhitungan peneliti, } & 2020 \\
& &
\end{tabular}

Sump pit direncanakan untuk menaikkan air limbah ke unit pengolahan berikutnya. Waktu detensi air limbah yang direncanakan Rekapitulasi perencanaan unit sump pit dapat dilihat Tabel 8. Perhitungan dimensi sump pit sebagai berikut.

Menghitung volume tangki dengan waktu detensi 10 menit.

- $\mathrm{V}=\mathrm{Q} \times \mathrm{Td}$

$\mathrm{V}=3,99 \mathrm{~m}^{3} / \mathrm{s} \times 600 \mathrm{~s}$

$\mathrm{V}=2.394 \mathrm{~m}^{3}$

Menghitung diameter tangki dengan kedalaman direncanakan $10 \mathrm{~m}$.

- $\mathrm{D}=(4 \times \mathrm{V} / \pi \times \mathrm{h})^{0,5}$

$\mathrm{D}=\left(4 \times 2.394 \mathrm{~m}^{3} / \pi \times 10 \mathrm{~m}\right)^{0,5}$

$\mathrm{D}=17 \mathrm{~m}$

Menentukan jumlah dan jenis pompa. Jumlah pompa yang dibutuhkan dilihat dari debit yang akan disalurkan. Debit yang lebih besar dari 11.370 L/menit dianjurkan menggunakan 6 buah pompa dengan konfigurasi 5 unit beroperasi dan 1 unit cadangan. Maka, debit tiap pompa:

- Qpompa=Q/5 unit pompa

Qpompa $=3,99 \mathrm{~m}^{3} / \mathrm{s} / 5$ unit pompa

Qpompa $=0,798 \mathrm{~m}^{3} / \mathrm{s}$

Qpompa $=0,798 \mathrm{~m}^{3} / \mathrm{s} \times 1.000 \mathrm{dm}^{3} / \mathrm{m}^{3} \times 86.400 \mathrm{~s} / \mathrm{jam}$

Qpompa $=2.872 \mathrm{~m}^{3} / \mathrm{jam}$

Jenis pompa yang digunakan adalah;

Tipe: AT600WQ4000-12-200

Kapasitas:3.000 m³/jam

Daya: $200 \mathrm{~kW}$

Tabel 8. Rekapitulasi hasil perencanaan dimensi unit Sump Pit

\begin{tabular}{|c|c|c|}
\hline Uraian & Satuan & Nilai \\
\hline Jumlah Unit & buah & 1 \\
\hline Waktu Detensi & menit & 10 \\
\hline Kedalaman & $\mathrm{m}$ & 10 \\
\hline Diameter & $\mathrm{m}$ & 17 \\
\hline Panjang & $\mathrm{m}$ & 0,5 \\
\hline Jumlah Pompa & unit & 6 \\
\hline
\end{tabular}

Sumber: Hasil perhitungan peneliti, 2020 
Grit chamber direncanakan untuk melindungi beberapa peralatan mekanis, mengurangi terbentuknya endapan dalam pipa dan saluran, serta tujuan utamanya adalah memisahkan grit (pasir, kerikil, dan material lainnya yang memiliki kecepatan pengendapan lebih besar dari partikel organik). Perhitungan dimensi grit chamber sebagai berikut.

Menghitung volume tangki grit chamber dengan waktu detensi $180 \mathrm{~s}$.

- $\mathrm{V}=\mathrm{Q} \times \mathrm{Td}$

$\mathrm{V}=3,99 \mathrm{~m}^{3} / \mathrm{s} \times 180 \mathrm{~s}$

$\mathrm{V}=718,2 \mathrm{~m}^{3}$

Menghitung panjang tangki dengan kedalaman $5 \mathrm{~m}$ dan lebar $7 \mathrm{~m}$.

- $\mathrm{V}=\mathrm{P} \times \mathrm{L} \times \mathrm{H}$

$\mathrm{P}=718,2 \mathrm{~m}^{3} / 7 \mathrm{~m} \times 5 \mathrm{~m}$ $\mathrm{P}=20,5 \mathrm{~m}$

Menghitung volume pengumpul grit, jika jumlah grit yang dikumpulkan mencapai $0,2 \mathrm{~m}^{3} / 1.000 \mathrm{~m}^{3}$ air limbah.

- Vgrit $=\left(0,2 \mathrm{~m}^{3} / 1.000 \mathrm{~m}^{3}\right) \times 3,99 \mathrm{~m}^{3} / \mathrm{s}$ Vgrit $=68,94 \mathrm{~m}^{3}$

Menghitung kedalaman pengumpul grit, jika direncanakan lebar pengumpul grit sama dengan panjang bak dan lebar saluran $3 \mathrm{~m}$.

- Vgrit $=$ Pgrit $\times$ Lgrit $\times$ Hgrit

Hgrit $=68,94 \mathrm{~m}^{3} /(20,5 \mathrm{~m} \times 3 \mathrm{~m})$

Hgrit $=1,12 \mathrm{~m}$

Menghitung kedalaman total tangki.

- Htotal $=\mathrm{H}+$ Hgrit

Htotal $=5 \mathrm{~m}+1,12 \mathrm{~m}$

Htotal $=6,12 \mathrm{~m}$

Rekapitulasi perencanaan unit aerated grit chamber dapat dilihat Tabel 9.

Tabel 9. Rekapitulasi hasil perencanaan dimensi unit Aerated Grit Chamber

\begin{tabular}{|c|c|c|}
\hline Uraian & Satuan & Nilai \\
\hline Jumlah Unit & buah & 2 \\
\hline Waktu Detensi & $\mathrm{s}$ & 180 \\
\hline Kedalaman & $\mathrm{m}$ & 5 \\
\hline Lebar & $\mathrm{m}$ & 7 \\
\hline Panjang & $\mathrm{m}$ & 20,5 \\
\hline Suplai Udara Flow rate (Af) & $\mathrm{m}^{3} / \mathrm{s} . \mathrm{m}$ & 0,0125 \\
\hline Letak diffuser (db) & $\mathrm{m}$ & 0,6 \\
\hline Kecepatan & $\mathrm{m} / \mathrm{s}$ & 0,0524 \\
\hline Jumlah timbulan Grit & $\mathrm{m}^{3}$ & 68,94 \\
\hline
\end{tabular}

Sumber: Hasil perhitungan peneliti, 2020

Instalasi yang menggunakan teknologi complete mix activated sludge membutuhkan primary clarifier. Primary clarifier atau disebut juga bak pengendap pertama dapat menyisihkan kandungan BOD. Rekapitulasi perencanaan unit aerated grit chamber dapat dilihat Tabel 10. Perhitungan dimensi unit clarifier I sebagai berikut.

Menghitung luas tangki menggunakan overflow rate sebesar $60 \mathrm{~m}^{3} / \mathrm{h} . \mathrm{m}^{2}$.

- Atangki $=\mathrm{Q} / \mathrm{vo}$

Atangki $=\left(3,99 \mathrm{~m}^{3} / \mathrm{s} \times 86.400 \mathrm{~s} / \mathrm{hari} / 4\right.$ unit $) / 60 \mathrm{~m}^{3} / \mathrm{h} . \mathrm{m}^{2}$

Atangki $=1.436,4 \mathrm{~m}^{2}$ per unit

Menghitung diameter tangki.

- $\mathrm{D}=(\text { Atangki } \times 4 / \pi)^{0,5}$

$\mathrm{D}=\left(1.436,4 \mathrm{~m}^{2} \times 4 / \pi\right)^{0,5}$

$\mathrm{D}=42 \mathrm{~m}$ 
Tabel 10. Rekapitulasi hasil perencanaan dimensi unit Clarifier I

\begin{tabular}{|c|c|c|}
\hline Uraian & Satuan & Nilai \\
\hline Jumlah Unit & buah & 4 \\
\hline Overflow rate & $\mathrm{m}^{3} / \mathrm{h} \cdot \mathrm{m}^{2}$ & 60 \\
\hline Waktu Detensi & Jam & 1,54 \\
\hline Flow velocity & $\mathrm{m} / \mathrm{s}$ & 0,029 \\
\hline Weir loading rate & $\mathrm{m}^{3} / \mathrm{h} . \mathrm{m}$ & 653,3 \\
\hline Diameter & $\mathrm{m}$ & 42 \\
\hline Kedalaman & $\mathrm{m}$ & 4 \\
\hline
\end{tabular}

Sumber: Hasil perhitungan peneliti, 2020

Unit complete mix activated sludge (CMAS) direncanakan dapat mengolah konsentrasi air limbah (khususnya BOD dan TSS) mencapai standar baku mutu kawasan Aerocity X. Rekapitulasi perencanaan unit complete mix activated sludge dapat dilihat Tabel 11. Perhitungan dimensi unit CMAS sebagai berikut.

Menghitung volume tangki. Tangki CMAS direncanakan sebanyak 6 unit.

- Qunit= Q / 6 tangki

Qunit $=3,99 \mathrm{~m}^{3} / \mathrm{s} / 6$ tangki

Qunit $=0,66 \mathrm{~m} 3 / \mathrm{s}$

- $\mathrm{V}=\{(\theta \mathrm{c} \times \mathrm{Y} \times \mathrm{Q} \times(\mathrm{Se}-\mathrm{S})\} /\{\mathrm{X}(1+\mathrm{kd} \times \theta \mathrm{c})\}$

$\mathrm{V}=\left\{\left(8 \mathrm{hari} \times 0,5 \times 0,66 \mathrm{~m}^{3} / \mathrm{s} \times(202 \mathrm{mg} / \mathrm{l}-18,62 \mathrm{mg} / \mathrm{l})\right\} /\{3.000 \mathrm{mg} / \mathrm{l}(1+0,05 /\right.$ hari $\times 8$ hari $)\}$

$\mathrm{V}=14.063,4 \mathrm{~m}^{3}$

Menghitung dimensi tangki. Direncanakan kedalaman bak $5 \mathrm{~m}$, tangki berbentuk persegi panjang.

- $\quad$ Atangki $=\mathrm{V} /$ Htangki

Atangki $=14.063,4 \mathrm{~m}^{3} / 5 \mathrm{~m}$

Atangki $=2.812,67 \mathrm{~m}^{2}$

- Atangki $=\mathrm{P} \times \mathrm{L}$

Atangki $=(2 \mathrm{~L}) \times \mathrm{L}$

$\mathrm{L}=($ Atangki/ 2$) 0,5$

$\mathrm{L}=\left(2.812,67 \mathrm{~m}^{2} / 2\right) 0,5$

$\mathrm{L}=37,5 \mathrm{~m}$

$\mathrm{P}=75 \mathrm{~m}$

Tabel 11. Rekapitulasi hasil perencanaan dimensi unit Complete Mix Activated Sludge

\begin{tabular}{lcc}
\hline \multicolumn{1}{c}{ Uraian } & Satuan & Nilai \\
\hline Jumlah Unit & buah & 6 \\
Mean cell residence time $(\theta c)$ & hari & 8 \\
Organic loading & $\mathrm{kg} \mathrm{BOD} / \mathrm{m}^{3} \cdot$ hari & 0,92 \\
Hydraulic retention time $(\theta)$ & $\mathrm{jam}$ & 2,48 \\
Rasio resirkulasi & - & 0,42 \\
Rasio F/M & - & 0,25 \\
MLVSS & $\mathrm{Mg} / \mathrm{l}$ & 3 \\
MLSS & $\mathrm{Mg} / \mathrm{l}$ & 3.75 \\
Panjang & $\mathrm{m}$ & 75 \\
Lebar & $\mathrm{m}$ & 37,5 \\
Kedalaman & $\mathrm{m}$ & 5 \\
Konstanta Pertumbuhan mikroba Kd & $\mathrm{d}^{-1}$ & 0,05 \\
Y & $\mathrm{mg} \mathrm{VSS} / \mathrm{mg}$ BOD & 0,5 \\
\hline
\end{tabular}

Sumber: Hasil perhitungan peneliti, 2020

Perencanaan teknologi CMAS diikuti dengan unit clarifier II yang berfungsi untuk mengendapkan padatan flokulasi yang besar dari efluen biologis. Rekapitulasi perencanaan unit clarifier II dapat dilihat Tabel 12. Perhitungan dimensi calrifier II dapat dilihat sebagai berikut.

Menghitung luas tangki menggunakan overflow rate sebesar $50 \mathrm{~m}^{3} / \mathrm{h} . \mathrm{m}^{2}$.

- $\quad$ Atangki $=\mathrm{Q} /$ vo

Atangki $=\left(3,99 \mathrm{~m}^{3} / \mathrm{s} \times 86.400 \mathrm{~s} / \mathrm{hari} / 6\right.$ unit $) / 50 \mathrm{~m}^{3} / \mathrm{h} . \mathrm{m}^{2}$

Atangki $=1.641,6 \mathrm{~m}^{2}$ per unit 
Menghitung diameter tangki.

- $\mathrm{D}=(\text { Atangki } \times 4 / \pi)^{0,5}$

$\mathrm{D}=\left(1.641,6 \mathrm{~m}^{2} \times 4 / \pi\right)^{0,5}$

$\mathrm{D}=46 \mathrm{~m}$

Tabel 12. Rekapitulasi hasil perencanaan dimensi unit Clarifier II

\begin{tabular}{lcc}
\hline Uraian & Satuan & Nilai \\
\hline Jumlah Unit & buah & 6 \\
Overflow rate & $\mathrm{m}^{3} / \mathrm{h} . \mathrm{m}^{2}$ & 50 \\
Waktu Detensi & $\mathrm{Jam}$ & 1,89 \\
Weir loading rate & $\mathrm{m} 3 / \mathrm{h} \cdot \mathrm{m}$ & 568 \\
Diameter & $\mathrm{m}$ & 46 \\
Kedalaman & $\mathrm{m}$ & 3,9 \\
\hline
\end{tabular}

Sumber: Hasil perhitungan peneliti, 2020

Instalasi pengolahan air limbah yang sudah direncanakan akan ditempatkan di Zona $C$, yang dipergunakan untuk Energy Center. Estimasi lahan yang dibutuhkan untuk mengolah air limbah di Kawasan Aerocity $X$ adalah $9.446,51 \mathrm{~m}^{2} / \mathrm{m}^{3}$ air limbah yang ditimbulkan. Rekapitulasi penggunaan lahan instalasi pengolahan air limbah dapat dilihat Tabel 13.

Tabel 13. Indeks kebutuhan lahan

\begin{tabular}{|c|c|c|c|c|}
\hline Unit & Jumlah & Luas (m2) & Luas total (m2) & $\begin{array}{c}\text { Indeks Kebutuhan Lahan } \\
\left(\mathrm{m}^{2} / \mathrm{m}^{3} \text { air limbah }\right)\end{array}$ \\
\hline Bar screen & 2 & 8 & 16 & 56,85 \\
\hline Sump Pit & 1 & 226,86 & 226,86 & 4,01 \\
\hline Grit chamber & 2 & 143,5 & 287 & 71,93 \\
\hline Clarifier I & 4 & $1.384,74$ & $5.538,96$ & $1.388,21$ \\
\hline Complete Mix Activated Sludge & 6 & $2.812,5$ & 16.875 & $4.229,32$ \\
\hline Clarifier II & 6 & $1.661,06$ & $14.247,8$ & $3.570,865$ \\
\hline Kantor & 1 & 500 & 500 & 125,31 \\
\hline Total & & & 37.692 & $9.446,51$ \\
\hline
\end{tabular}

Sumber: Hasil perhitungan peneliti, 2020

Instalasi pengolahan air limbah yang sudah direncanakan akan ditempatkan di Zona $\mathrm{C}$, yang dipergunakan untuk Energy Center. Estimasi lahan yang dibutuhkan untuk mengolah air limbah di Kawasan Aerocity $X$ adalah $9.446,51 \mathrm{~m}^{2} / \mathrm{m}^{3}$ air limbah terolah.

Perencanaan instalasi pengolahan air limbah di Kawasan Industri Aerocity X Kabupaten Majalengka terdiri dari beberapa unit. Rencana anggaran biaya untuk pembangunan IPAL di kawasan tersebut terdiri dari pekerjaan persiapan, pembangunan masing-masing unit pengolahan, alokasi jasa dan PPN sebesar 10\%. Hasil rekapitulasi rencana anggaran biaya dapat dilihat Tabel 14.

Tabel 14. Indeks kebutuhan biaya

\begin{tabular}{|c|c|c|}
\hline No. & Uraian Pekerjaan & $\begin{array}{c}\text { Indeks Kebutuhan Biaya } \\
\text { (per } \mathrm{m}^{3} \text { air limbah) }\end{array}$ \\
\hline 1. & Pekerjaan Persiapan Pembangunan & Rp31.369.899,37 \\
\hline 2. & Pembangunan Bar Screen & Rp23.109.915,93 \\
\hline 3. & Pembangunan Sump Pit & Rp51.822.249,83 \\
\hline 4. & Pembangunan Grit Chamber & Rp85.391.690,77 \\
\hline 5. & Pembangunan Clarifier I (4 unit) & Rp521.615.247,09 \\
\hline 6. & Pembangunan CMAS (6 unit) & Rp2.776.312.614,81 \\
\hline 7. & Pembangunan Clarifier II (6 unit) & Rp1.154.619.644,52 \\
\hline A. & Sub Total I $(1+2+3+4+5+6+7)$ & Rp4.644.241.262,32 \\
\hline B. & Jasa $10 \%$ & Rp464.424.126,23 \\
\hline C. & Sub Total II (A+B) & Rp5.108.665.388,55 \\
\hline \multirow[t]{2}{*}{ D. } & PPN $10 \%$ & Rp510.868.538,85 \\
\hline & JUMLAH TOTAL (C+D) & Rp5.619.531.927,40 \\
\hline
\end{tabular}




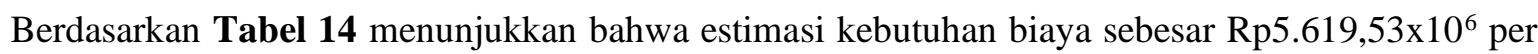
$\mathrm{m}^{3}$ air limbah terolah. IPAL direncanakan dapat mengolah air limbah menggunakan sistem pompa dan gravitasi, gambar profil hidrolis dapat dilihat pada Gambar 2.

\begin{tabular}{|c|c|c|c|c|c|c|}
\hline $\begin{array}{c}\text { Unit } \\
\text { Pengolahan }\end{array}$ & Screen & $\begin{array}{l}\text { Sump } \\
\text { Pit }\end{array}$ & $\begin{array}{l}\text { Aerated } \\
\text { Grit } \\
\text { Chamber }\end{array}$ & Clarifier I & $\begin{array}{l}\text { Complete mix Activated } \\
\text { Sludge }\end{array}$ & Clarifier II \\
\hline $\begin{array}{c}\text { Elevasi } \\
\text { Muka } \\
\text { Tanah }\end{array}$ & $+38 \mathrm{~m}$ & $+38 \mathrm{~m}$ & $+38 \mathrm{~m}$ & $+38 \mathrm{~m}$ & $+36,5 \mathrm{~m}$ & $+36,5 \mathrm{~m}$ \\
\hline $\begin{array}{c}\text { Kedalaman } \\
\text { Galian } \\
\text { Terhadap } \\
\text { Muka Air }\end{array}$ & $3 \mathrm{~m}$ & $3 \mathrm{~m}$ & $0 \mathrm{~m}$ & $0 \mathrm{~m}$ & $1,5 \mathrm{~m}$ & $1,5 \mathrm{~m}$ \\
\hline $\begin{array}{l}\text { Ketinggian } \\
\text { Air }\end{array}$ & $+34,5 \mathrm{~m}$ & $\begin{array}{c}+34,5 \\
\mathrm{~m}\end{array}$ & $+37,5 \mathrm{~m}$ & $+36,75 \mathrm{~m}$ & $+36 \mathrm{~m}$ & $+35,5 \mathrm{~m}$ \\
\hline $\begin{array}{l}\text { Panjang } \\
\text { Bak }\end{array}$ & $10 \mathrm{~m}$ & $17 \mathrm{~m}$ & $10 \mathrm{~m}$ & $42 \mathrm{~m}$ & $75 \mathrm{~m}$ & $46 \mathrm{~m}$ \\
\hline
\end{tabular}

Gambar 2. Profil hidrolis pengolahan air limbah kawasan Aerocity $X$

Sumber: Hasil analisis peneliti, 2020

\section{Kesimpulan}

Berdasarkan hasil perencanaan instalasi pengolahan air limbah yang diterapkan pada Kawasan Aerocity X menggunakan teknologi pengolahan biologis yaitu Complete Mix Activated Sludge (CMAS). Rangkaian instalasi pengolahan yang direncanakan yaitu bar screen, sump pit, grit chamber, clarifier I, completed mix activated slude, dan clarifier II dengan nilai indeks kebutuhan lahan yang dibutuhkan senilai $9.446,5 \mathrm{~m}^{2} / \mathrm{m}^{3}$ air limbah terolah. Sedangkan rencana anggaran biaya untuk perencanaan instalasi

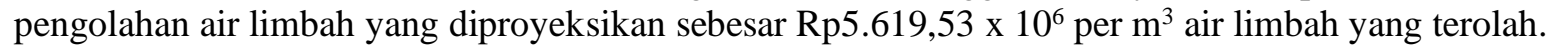

\section{Referensi}

[1] Pemerintah Daerah Kabupaten Majalengka, “RPIJM Kabupaten Majalengka 2015 - 2019," pp. 5-37, 2011.

[2] P. L. ITB, "Rencana Bisnis Energy Center Aerocity," 2018.

[3] S. Jafarinejad, "Economic Analysis: Trickling Filter/Activated Sludge or Nitrifying Trickling Filter/Activated Sludge?," Ecological Chemistry and Engineering S, vol. 26, no. 2. Sciendo, pp. 345-356, 2019.

[4] M. Pekerjaan, U. Dan, P. Rakyat, and R. Indonesia, "JDIH Kementerian PUPR,” vol. 5, pp. 1-20, 2016.

[5] A. Alatas, Perencanaan Pembangunan Sistem Distribusi Air Minum di Kecamatan Muara Enim Kabupaten Muara Enim Provinsi Sumatera Selatan. Bandung: ITENAS, 2017.

[6] G. A. Rahmawati, Perencanaan Instalasi Pengolahan Air Limbah Mal X Kota Bandung. Bandung: ITENAS, 2019.

[7] N. Wikaningrum, T., Kebijakan Pengelolaan Lingkungan Kawasan Industri Sesuai Proper KLHK Peringkat Hijau (Studi Kasus di Kawasan Industri Jababeka Bekasi. Bogor: IPB, 2015.

[8] N. I. Said, "Pengolahan Air Limbah Rumah Sakit Dengan Proses Biologis Biakan Melekat Menggunakan Media Palstik Sarang Tawon,” J. Teknol. Lingkung., vol. 2, no. 3, 2011. 
[9] P. D. Mackenzie L. Davis P.E., DEE, Water and Wastewater Engineering: Design Principles and Practice. New York: McGraw-Hill Education, 2010.

[10] S. Asmadi, Dasar-dasar Teknologi Pengolahan Air Limbah. Yogyakarta: Gosyen Publishing, 2012.

[11] G. L. Karia and R. A. Christian, Wastewater Treatment: Concepts and Design Approach. 2013.

[12] I. P. Ginting, "Sistem Pengelolaan Lingkungan dan Limbah Industri," 2018. 